\title{
Upaya Meningkatkan Kinerja Guru Produktif dalam Melaksanakan Pembelajaran Membatik pada Program Keahlian Desain dan Produksi Kria Tekstil melalui Pembinaan Kompetensi Profesional
}

\author{
I Gst Ngurah Made Umbara \\ SMK Negeri 2 Sukawati \\ e-mail: umbaramade45@gmail.com
}

\begin{abstract}
Abstrak
Berdasarkan dari hasil pengamatan pada tahap awal yang dilakukan Peneliti menunjukkan bahwa, (1) Perencanaan yang dilakukan guru dalam pembelajaran batik adalah mempersiapkan perangkat pembelajaran, yaitu silabus dan rencana pelaksanaan pembelajaran (RPP). Komponen dalam silabus yaitu: Standar kompetensi dan kompetensi dasar, materi pembelajaran, kegiatan pembelajaran, indikator, penilaian, alokasi waktu, dan sumber belajar. Sedangkan komponen dalam RPP yaitu: Tujuan pembelajaran, materi pembelajaran, strategi dan metode pembelajaran, media dan sumber pembelajaran, dan penilaian hasil belajar belum tersedia sesuai dengan kelengkapannya. (2) Proses pembelajaran batik pada pertemuan pertama diawali dengan persepsi kemudian guru menjelaskan tentang pengertian batik tulis klasik dan jenis-jenis ragam hias. Pertemuan kedua, penugasan kepada peserta didik untuk membuat jenis ragam hias dan desain karya batik. Pertemuan ketiga, guru menjelaskan prosedur dalam pembuatan karya batik tulis sesuai urutan langkah kerja belum terlaksana secara sistematis. Melihat kondisi demikian Penedliti berupaya melakukan perbaikan-perbaikan melalui Penelitian Tindakan Sekolah dengan menerapkan pembinaan Kompetensi Profesional bagi guru Produktif. Karena dengan cara ini diyakini dapat meningkatkan kinerja guru produktif pada tingkat yang lebih baik dan sistematis. Penelitian Tindakan Sekolah ini bertujuan untuk meningkatkan kinerja guru produktif dalam melaksanakan pembelajaran membatik. Kegiatan Penelitian dilakukan di SMK Negeri 2 Sukawati pada bulan Juli tahun 2017 dengan objek guru produktif sebanyak 15 orang Pelaksanaan Penelitian Tindakan Sekolah ini dilakukan secara kolaboratif dengan partisipatif pelaksanaannya selama 2 siklus penelitian. Data hasil penelitian yang telah dikumpulkan melalui penelitian ini kemudian dianalisis menggunakan analisis deskriptif. Hasil penelitian menunjukkan adanya peningkatan kinerja guru produktif dalam melaksanakan pembelajaran membatik bagi siswa Program Keahlian Desain dan Produksi Kria Tekstil. Berdasarkan data yang diperoleh dalam Penelitian Tindakan Sekolah (PTS) ini maka dapat disimpulkan bahwa pelaksanaan pembinaan Kompetensi Profesional dapat meningkatkan kinerja guru produktif dalam melaksanakan pembelajaran membatik di SMK Negeri 2 Sukawati program keahlian desain dan produksi kria Tekstil tahun pelajaran $2017 / 2018$.
\end{abstract}

Kata Kunci: Peningkatan Kinerja Guru Produktif, Pembinaan Kompetensi Profesional

\section{Abstract}

Based on the results of the observations at the initial stage, the Researcher showed that, (1) Planning carried out by the teacher in batik learning is preparing learning devices, namely syllabus and plan for implementing learning (RPP). Components in the syllabus are: Standard competencies and basic competencies, learning materials, learning activities, indicators, assessment, time allocation, and learning resources. While the components in the lesson plan are: Learning objectives, learning materials, learning strategies and methods, media and sources of learning, and assessment of learning outcomes are not yet available with the completeness. (2) The process of learning batik at the first meeting begins with apperception and the teacher explains about the understanding of classical written batik and the types of ornamental variety. The second meeting, assignments to students to make kinds of decorations and designs of batik works. The third meeting, the teacher explained the procedure in making batik works according to the sequence of work steps that had not been carried out systematically. Seeing this condition, Researcher is able to make improvements through School Action Research by implementing the development of Professional Competence for Productive teachers. Because in this way it is believed that it can improve the performance of productive 
teachers at a better and systematic level. This school action research aims to improve the performance of productive teachers in carrying out batik learning. The research activity was conducted at SMK Negeri 2 Sukawati in July 2017 with 15 productive teachers as the object. The Implementation of School Action Research was conducted collaboratively with participatory implementation for 2 research cycles. Data from research results that have been collected through this study were then analyzed using descriptive analysis. The results of the study indicate an increase in the performance of productive teachers in carrying out batik learning for students in the Program of Design and Production of Textile Crafts. Based on the data obtained in this School Action Research, it can be concluded that the implementation of Professional Competence coaching can improve the performance of productive teachers in carrying out batik learning at Sukawati Vocational School 2 in the design and production program of the textile school for the 2017/2018 school year.

Keywords: Increasing the performance of productive teachers, fostering professional competence

\section{Pendahuluan}

Perkembangan ilmu pengetahuan dan teknologi dalam era globalisasi seperti sekarang ini, sangat mempengaruhi berbagai dimensi kehidupan manusia baik itu kehidupan sosial, ekonomi, pendidikan dan kebudayaan. Lanjunya perkembangan ilmu pengetahuan dan teknologi tersebut mempengaruhi kualitas sumber daya manusia. Belajar merupakan proses dari pendidikan untuk meningkatkan sumber daya manusia, proses belajar pada umumnya dilaksanakan disekolah oleh dua pihak yaitu guru dan siswa. Hal ini berarti berhasil tidaknya pencapaian tujuan belajar bergantung pada bagaimana proses belajar mengajar yang dijalani oleh siswa sebagai peserta didik yang menjadi tanggung jawab guru sebagai pendidik. Menurut Asiah (2016) kinerja merupakan terjemahan dari kata performance (Job Performance), secara etimologis performance berasal dari kata to perform yang berarti menampilkan atau melaksanakan, sedang kata performance berarti "The act of performing; execution" (Webster Super New School and Office Dictionary), Dari pengertian tersebut dapat disimpulkan bahwa kinerja atau performance berarti tindakan menampilkan atau melaksanakan suatu kegiatan, oleh karena itu performance sering juga diartikan penampilan kerja atau prilaku kerja. Menurut Zubair (2017) kinerja guru adalah persepsi guru terhadap prestasi kerja guru yang berkaitan dengan kualitas kerja, tanggung jawab, kejujuran, kerjasama dan prakarsa. Kompensasi yang diberikan kepada guru sangat berpengaruh pada tingkat kepuasan kerja, motivasi kerja, dan hasil kerja. Apabila kompensasi yang diberikan dengan mempertimbangkan standar kehidupan normal dan dapat memenuhi kebutuhankebutuhan guru maka dengan sendirinya akan mempengaruhi semangat kerjanya, yang pada gilirannya akan meningkatkan kualitas setiap pekerjaan yang dilakukan. Menurut Slameto (2017) Salah satu indikator kinerja guru adalah memiliki karya penelitian dan publikasi. Namun dalam prakteknya, banyak guru mengalami kendala dalam penelitian dan publikasinya 2) Latihan Instruksi Pekerjaan (Job Instruction Learning), 3) Magang (Apprenticeship), 4) Coaching, 5) Penugasan sementara. Menurut Srinalia (2015) Guru adalah unsur manusiawi dalam pendidikan. Guru adalah figur manusia sumber yang menempati posisi dan memegang peranan penting dalam pendidikan. Di sekolah guru hadir untuk mengabdikan diri kepada umat manusia dalam hal ini peserta didik. Negara menuntut generasinya yang memerlukan pembinaan dan bimbingan dari guru. Guru dengan sejumlah buku yang terselip dipinggang datang ke sekolah di waktu pagi hingga petang, sampai waktu mengajar dia hadir di kelas untuk bersama-sama belajar dengan sejumlah peserta didik yang sudah menantinya untuk diberikan pelajaran. Salah satu faktor utama yang menentukan mutu pendidikan adalah guru. Gurulah yang berada di garda terdepan dalam menciptakan kualitas sumber daya manusia. Guru berhadapan langsung dengan para peserta didik di kelas melalui proses belajar mengajar. Menurut Ning Zahroh (2016) Salah satu faktor utama yang sangat menentukan dalam meningkatkan mutu pendidikan adalah tersedianya guru profesional yang mampu melaksanakan tugas pembelajaran dengan penuh tanggung jawab. Menurut Niken (2017) mutu pendidikan merupakan salah satu tolak ukur yang menentukan martabat atau kemajuan suatu bangsa. Mencermati mutu pendidikan suatu bangsa atau negara, seseorang akan dapat memperkirakan peringkat negara tersebut di antara negara-negara di dunia. Oleh karena itu, bangsa yang maju akan selalu menaruh perhatian besar terhadap dunia pendidikannya dengan melakukan berbagai upaya untuk meningkatkan mutu pendidikan. 
Menurut Ode (2017) Mutu pendidikan sering diartikan sebagai karakteristik jasa pendidikan yang sesuai dengan kriteria tertentu untuk memenuhi kepuasan pengguna (user) pendidikan, yakni peserta didik, orang tua, serta pihak-pihak berkepentingan lainnya. Dalam menjaga mutu proses tersebut, diperlukan adanya quality control yang mengawasi jalannya proses dan segala komponen pendukungnya. Menurut Khodijah (2013) Guru memegang peran utama dalam pendidikan, khususnya pendidikan yang diselenggarakan secara formal di sekolah / madrasah. Guru sangat menentukan keberhasilan peserta didik, terutama dalam kaitannya dengan proses pembelajaran. Guru merupakan komponen yang paling berpengaruh terhadap terciptanya proses dan hasil pendidikan yang berkualitas. Oleh karena itu, upaya perbaikan apapun yang dilakukan untuk meningkatkan kualitas pendidikan tidak akan memberikan sumbangan yang signifikan tanpa didukung oleh guru yang profesional dan berkualitas. Begitu pentingnya peran guru dalam proses pendidkan, maka seorang guru dituntut untuk selalu meningkatkan kemampuan dan kinerjanya sebagai tenaga yang bermartabat dan profesional.

SMK N 2 Sukawati adalah salah satu Sekolah Menengah Kejuruan (SMK) yang berada dalam kampus SMK yang berlokasi di Kecamatan Sukawati, Batubulan Kabupaten Gianyar dan melaksanakan 8 ( delapan) Program Keahlian yaitu : 1) Program Keahlian Desain dan Produksi Kria Kayu, 2) Program Keahlian Desain dan Produksi Kria Logam, 3) Program Keahlian Desain dan Produksi Kria Keramik, 4) Program Keahlian Desain dan Produksi Kria Tekstil, 5) Program Keahlian Multimedia, 6) Program Keahlian Jasa Boga, 7) Program Keahlian Busana Butik, dan 8) Program Keahlian Akomodasi Perhotelan

Dalam Program Keahlian Desain dan Produksi Kria Tekstil menjadi konsentrasi dari Penelitian Tindakan Sekolah ini karena cakupan dari program keahlian ini mempunyai ruang lingkup Kompetensi Keahlian yaitu: 1) Desain produk kria tekstil, 2) Membatik, 3) Cetak saring / Sablon, 4) Desain mode dan aplikasi, 5) Teknik jahit, 5) Teknik Painting

Membatik adalah salah satu kompetensi keahlian yang menyatu dengan pembelajaran membatik dimana kelihatan pembelajaran diawali dengan menggambar ornamen (motif), menyusunnya menjadi satu desain lalu memindahkannya kedalam kain. Batik adalah lukisan yang dibuat pada kain dengan bahan lilin dan pewarna (naptol) menggunakan alat canting. Sebagai bahan busana, batik memiliki corak yang khas, dengan memanfaatkan ornamenornamen daerah dan batikpun memiliki corak yang beragam.

Dari hasil observasi yang Peneliti lakukan bahwa kemampuan siswa dalam membatik belum menunjukkan hasil yang sesuai dengan pengetahuan yang dipelajarinya. Hal ini disebabkan karena kemampuan guru dalam mentransver pengetahuan dalam bentuk praktek masih kurang. Dalam mengajar membatik guru belum menggunakan perangkat pembelajaran membatik secara lengkap. Semua dokumen tersebut merupakan satu kesatuan yang tidak dipisahkan untuk mendukung kelancaran pelaksanaan kegiatan Belajar Mengajar.

Dengan keadaan demikian, peneliti sebagai pembina sekolah berusaha untuk memberi bimbingan dan pendampingan pada guru untuk meningkatkan kinerjanya dalam mengajar. Sehubungan dengan hal tersebut diatas maka dalam Penelitian Tindakan Sekolah (PTS) Peneliti mengambil judul: Upaya Meningkatkan Kinerja Guru Produktif dalam Melaksanakan Pembelajaran Membatik pada Program Keahlian Disain dan Produksi Kria Tekstil Melalui Pembinaan Kompetensi Profesional SMK Negeri 2 Sukawati Tahun Pelajaran 2017/2018.

Adapun tujuan yang ingin dicapai pada penelitian ini adalah: untuk mengetahui peningkatan kinerja guru Produktif SMK Negeri 2 Sukawati pada Program Keahlian Desain dan Produksi Kria Tekstil dalam melaksanakan pembelajaran membatik setelah dilaksanakannya pembinaan Kompitensi Profesional.

\section{Metode}

Penelitian ini adalah Penelitian Tindakan Sekolah (PTS) sehingga dalam pelaksanaannya menekankan pada peningkatan kinerja guru produktif dalam melaksanakan pembelajaran membatik bagi siswa Program Keahlian desain dan produksi kriya tekstil, SMK Negeri 2 Sukawati. Subjek penelitian sebanyak 15 guru Produktif Program Keahlian desain dan produksi kria tekstil. Guru produktif pada program keahlian desain dan produksi kria tekstil sebagai subjek penelitian karena rata-rata hasil belajar siswa dalam pembelajaran membatik belum mencapai standar nilai yang ditetapkan sekolah yakni 79 .

Dari hasil observasi yang dilakukan oleh peneliti pada awal penelitian ini (pra siklus) hanya mencapai $10 \%$ guru produktif yang mernunjuukkan kinerja mengajar dengan baik dan sebanyak $85 \%$ guru produktif pada program keahlian desain dan produksi kria tekstil yang belum menunjukkan kinerja mengajar secara tuntas, dan nampak hasil belajar siswa rendah. 
Penelitian ini dilakukan pada semester dua tahun pelajaran 2017/2018. Dilakukan sebanyak 2 siklus. Masing-masing siklus terdiri 2 kali pertemuan. Waktu Penelitian mulai dari Perencanaan sampai dengan penulisan laporan hasil penelitian tersebut mulai dari bulan Juli s.d Oktober 2017, tahun pelajaran 2017/2018.

Pelaksanaan Penelitian Tindakan Sekolah ini terdiri dari dua siklus, dimana setiap siklus terdiri dari empat komponen yaitu :

1. Perencanaan

a. Menyusun Program Pembelajaran dan Proposal Penelitian

b. Memilih masalah

c. Studi pendahuluan

d. Merumuskan permasalahan

e. Memilih Pendekatan

f. Menentukan variabel

g. Menentukan sumber data

h. Mempersiapkan alat dan bahan

i. Menyusun instrument tes uji komptensi dan lembar observasi

2. Pelaksanaan Tindakan

a. Kegiatan yang dilaksanakan pada tahap ini adalah melaksanakan pembelajaran sebagaimana skenario pembelajaran yang telah ditetapkan pada RPP

b. Tindakan adalah suatu perbaikan-perbaikan yang dilakukan terhadap guru yang masih mengalami masalah dalam meningkatkan kinerja serta mutu KBM dalam melaksanakan pembelajaran yang menjadi kosentrasi dalam Penelitian Tindakan Sekolah ini

3. Pengamatan

a. Pada tahap ini dilakukan proses observasi terhadap pelaksanaan tindakan dengan menggunakan lembar observasi yang telah dibuat

b. Pelaksanaan observasi bersama dengan Kepala sekolah atau guru dari SMK lainnya atau teman dari SMK yang sama sebagai kolaborator dalam Penelitian ini

4. Refleksi

Setiap siklus saling berkaitan dan berhubungan, karena hasil refleksi akan digunakan sebagai acuan untuk perbaikan pada siklus berikutnya. Diharapkan setiap siklus ada peningkatan yang signifikan mengenai peningkatan kinerja guru produktif dalam melaksanakan pembelajaran membatik. Pelaksanaan bimbingan bagi guru yang kemampuannya belum optimal dalam melaksanakan pembelajaran membatik, serta berkaitan dengan penyusunan perangkat pembelajaran.

Penyusunan Instrumen Penelitian ini terdiri dari : 1) Instrumen Penilaian kinerja guru, melihat hasil pembelajaran membatik pada siswa dan pembuatan perangkat dokumen pembelajaran yang disusun oleh guru, 2) Instrumen wawancara, untuk menjaring data melalui wawancara, 3) Instrumen Pengamatan, untuk menjaring data melalui pengamatan, melihat kemampuan guru dalam mengajar dan membimbing siswa, dan 4) Instrumen isian oleh objek atau guru, untuk menjaring data melalui isian dari responden (guru)

Indikator kinerja dibutuhkan dalam penelitian ini agar pelaksanaannya dapat mendatangkan hasil yang positif dan sesuai dengan apa yang dikehendaki yaitu meningkatnya kinerja guru produktif dalam melaksanakan pembelajaran membatik di SMK 2 Sukawati Program Keahlian desain dan produksi kria tekstil. Di harapkan dalam penelitian ini terdapat peningkatan mutu KBM mata pelajaran produktif untuk pembelajaran membatik. Dimana nantinya akan berdampak pada peningkatan hasil belajar siswa di SMK Negeri 2 Sukawati pada tingkat yang lebih baik. Hasil akhir yang diperoleh adalah meningkatnya kualitas tamatan siswa SMK Negeri 2 Sukawati sehingga daya serap lulusan di dunia kerja menjadi optimal.

\section{Hasil dan Pembahasan}

Dari hasil wawancara terhadap 15 orang guru, peneliti memperoleh informasi bahwa sebagian besar guru-guru produktif pada program keahlian desain dan produksi kriya tekstil yang memiliki kinerja dibawah rata-rata dalam melaksanakan pembelajaran membatik. Untuk itu guru-guru perlu pendampingan secara kontiniuw berupa pembinaan dari kepala sekolah dalam upaya meningkatkan kinerjanya.

Tujuan dari pengambilan data awal melalui tes Prasiklus adalah Peneliti ingin mengetahui kondisi sebenarnya tentang kinerja guru produktif dalam melaksanakan pembelajaran membatik. Pengambilan data pra siklus menggunakan instrumen yang sama dalam penelitian ini dan juga digunakan pada siklus berikutnya. Adapun hasil pra siklus yang 
dapat dihimpun adalah sebagai berikut: 1) Hanya 8 orang guru yang mencapai ketuntasan dalam melaksanakan pembelajaran membatik bagi siswa Program Keahlian desain dan produksi kria tekstil, 2) Sebanyak 7 orang guru yang belum mencapai ketuntasan dalam melaksanakan pembelajaran membatik, 3) Jumlah rata-rata nilai 37,06, 4) Guru yang mencapai ketuntasan dalam melaksanakan pembelajaran adalah $53,33 \%, 5$ ) Guru yang belum mencapai ketuntasan dalam melaksanakan pembelajaran sebanyak $46,67 \%$

Adapun masalah yang terdapat dalam tes pra siklus terhadap guru yang belum tuntas dalam melaksanakan pembelajaran membatik adalah: 1) Belum tercapainya kompetensi yang meliputi pengetahuan, keterampilan dan sikap siswa yang menjadi tolak ukur dalam pembelajaran, 2) Kemampuan Guru dalam menentukan suatu kepastian terhadap siswa yang menguasai kompetensi yang diharapkan dalam suatu materi ajar membatik masih rendah, 3) Standar Kompetensi, Kompetensi Dasar dan Indikator yang ditetapkan dalam kurikulum ketercapaiannya masih rendah, 4) Kemampuan guru dalam menuntun siswa untuk belajar lebih semangat masih rendah, 5) Guru membiarkan siswa mengerjakan tugas sendiri dan tidak dibimbing oleh guru, dan 6) Tingkat pemahaman siswa dalam penguasaan konsep membatik masih rendah.

Kondisi demikian perlu dilakukan perbaikan melalui refleksi dalam bentuk pembinaan kompetensi profesional bagu guru produktif pada program keahlian desain dan produksi kria tekstil melalui Penelitian Tindakan Sekolah ini. Peneliti mengamati guru dalam mengikuti bimbingan kepada siswa sekaligus memberikan tuntunan untuk meningkatkan pemahamannya.

Berdasarkan penelitian yang dilakukan pada siklus I didapatkan hasil sebagai berikut: 1) Sebanyak 12 orang guru yang telah mencapai ketuntasan dalam melaksanakan pembelajaran sehingga kinerjanya meningkat, 2) Sebanyak 3 orang guru yang belum mencapai ketuntasan dalam melaksanakan pembelajaran sehingga kinerjanya belum meningkat, 3) Jumlah rata-rata nilai adalah $43,53,4)$ Pada siklus I telah terjadi peningkatan kinerja guru produktif dalam nmelaksanakan pembelajaran membatik, 5) Pada siklus I masih ada 3 orang guru yang belum dapat menuntaskan tugasnya dalam melaksanakan pembelajaran sehingga belum mencapai ketuntasan dan masih memerlukan bimbingan dalam bentuk pembinaan, 6) Pelaksanaan fasilitasi melalui pembinaan kompetensi profesional terhadap guru produktif masih di perlukan dan tindakan masih berlanjut di siklus II, 7) Untuk mencapai peningkatan kinerja guru dalam melaksanakan pembelajaran pembinaan yang lebih intensif masih perlu ditingkatkan, dan 8) Kondisi demikian perlu dilakukan perbaikan melalui refleksi dalam bentuk bimbingan dan pembinaan kompetensi profesional yang dilakukan pada siklus II. Pada Siklus II akan dilakukan penyempurnaan-penyempurnaan melalui bimbingan khusus. Dengan melakukan tindakan terhadap guru yang belum mencapai ketuntasan dalam melaksanakan pembelajaran di siklus I, maka pelaksanaan pembinaan masih dilanjutkan pada siklus II.

Selanjutnya hasil tersebut akan disajikan dalam bentuk gambar grafik. Berikut ini capaian hasil yang dicapai pada pra siklus dan siklus I terhadap kinerja guru dalam melaksanakan pembelajaran membatik:

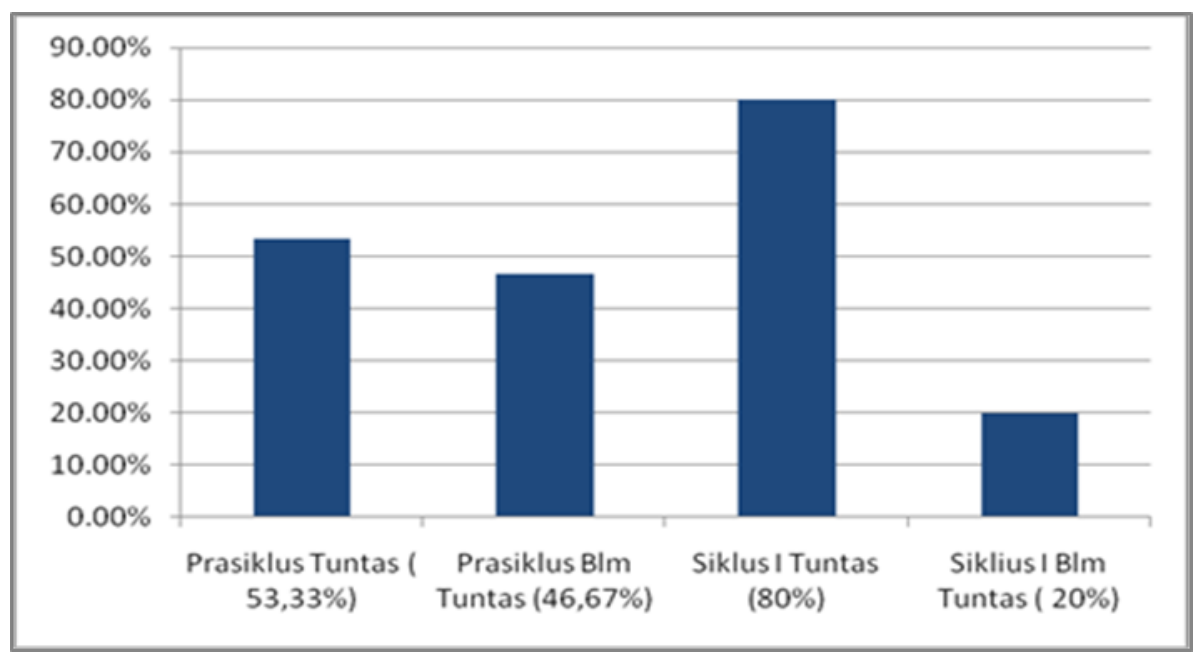

Gambar 1. Capaian Hasil yang Dicapai pada Pra Siklus dan Siklus I 
Keterangan:

1. Ketuntasan yang dicapai Guru pada Prasiklus $=53,33 \%$

2. Guru yg belum tuntas pada Prasiklus $=46,67 \%$

3. Ketuntasan yang dicapai guru pada siklus I $=80 \%$

4. Guru yang belum tuntas pada siklus I $\quad=20 \%$

Hasil siklus II menunjukkan bahwa telah terjadi peningkatan kinerja guru dalam melaksanakan pembelajaran membatik setelah dilaksanakan pembinaan kompetensi profesional secara konsisten.

Sebanyak 15 orang guru telah menuntaskan tugasnya dengan baik pada siklus II dan hasil pembelajaran membatik yang dicapai oleh siswa telah mencapai peningkatan dan siswa dapat menghasilkan produk atau karya batik yang sesuai dengan standar industri batik.

Setelah dilaksanakannya program pembinaan kompetensi profesional pada siklus II maka hasil yang dicapai dalam upaya meningkatkan kinerja guru produktif dalam melaksanakan pembelajaran adalah sebagai berikut: 1) Sebanyak 15 orang guru produktif pada program keahlian desain dan produksi kria tekstil telah mencapai ketuntasan dalam melaksanakan pembelajaran membatik, 2) Sebanyak 15 orang guru produktif pada program keahlian disain dan produksi kria tekstil yang di observasi dalam Penelitian Tindakan Sekolah ini telah mampu menunjukkan hasil dengan baik sesuai dengan tujuan yang ingin dicapai dalam Penelitian Tindakan Sekolah ini, 3) Nilai rata-rata yang dicapai pada siklus II adalah 46,33 suatu peningkatan yang dicapai guru pada siklus II, 4) Ketuntasan dalam melaksanakan pembelajaran telah dicapai $100 \%$ pada siklus II, dan 5) Pelaksanaan pembinaan kompetensi profesional bagi guru produktif pada program keahlian desain dan produksi kria tekstil dalam upaya meningkatkan kinerja mengajar membatik telah terbukti dengan baik. Melalui pembinaan kompetensi profesional guru memperoleh pengalaman secara efektif di sekolah tempat mengajar dan dilaksanakan berdasarkan kebutuhan riil guru serta pihak sekolah, pesertanya adalah guru dari sekolah tersebut yang kemampuannya belum optimal dalam melaksanakan pembelajaran membatik untuk menghasilkan karya siswa yang sesuai standar.

Selanjutnya hasil tersebut akan disajikan dalam bentuk gambar grafik. Berikut ini capaian hasil pada prasiklus, Siklus I dan Siklus II dapat disajikan dalam bentuk gambar grafik seperti yang tertuang dibawah ini:

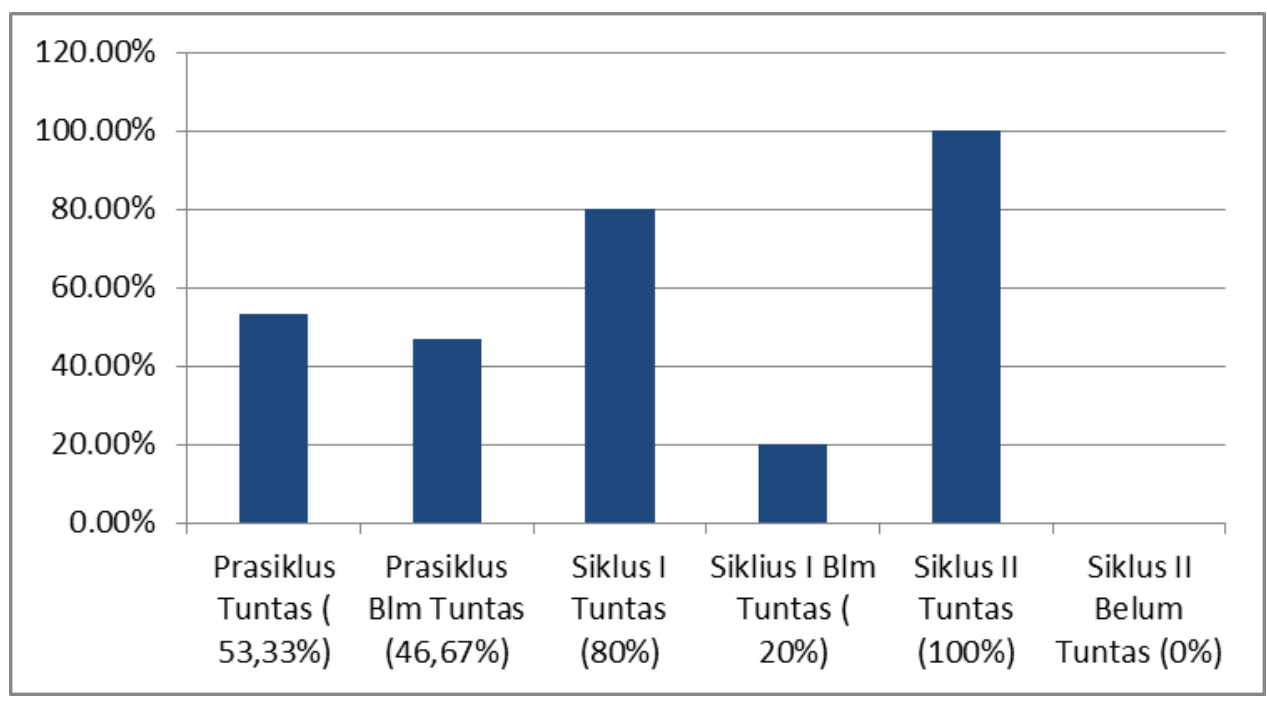

Gambar 2. Capaian Hasil yang Dicapai pada Prasiklus, Siklus I, dan Siklus II

Keterangan :

1. Ketuntasan yang dicapai Guru pada Prasiklus

$$
\begin{aligned}
& =53,33 \% \\
& =46,67 \% \\
& =80 \% \\
& =20 \% \\
& =100 \% \\
& =0 \%
\end{aligned}
$$$$
\text { . Guru yg belum tuntas pada Prasiklus }
$$$$
\text { 3. Ketuntasan yang dicapai guru pada siklus I }
$$$$
\text { 4. Guru yang belum tuntas pada siklus I }
$$$$
\text { 5. Guru yang tuntas pada Siklus II }
$$$$
\text { 6. Guru yang belum tuntas pada siklus II }
$$ 
Hasil penelitian di atas, sejalan dengan penelitian yang dilakukan oleh Fitriani, dkk. (2015) yang berjudul Kompetensi Profesional Guru dalam Pengelolaan Pembelajaran di Mts Muhammadiyah Banda Aceh. Dalam penelitiannya dinyatakan bahwa: (1) kompetensi yang dimiliki guru dalam merencanakan pembelajaran dalam menyusun RPP, penyusunan silabus, merencanakan media dan sumber pembelajaran serta merencanakan evaluasi pembelajaran sesuai dengan petunjuk yang ditetapkan, tetapi ada beberapa guru mengajar tidak membuat perencanaan pembelajaran; (2) strategi profesional guru dalam mengimplementasikan pembelajaran yaitu: menguasai materi, struktur, konsep dan pola pikir keilmuan yang mendukung mata pelajaran yang diajarkan. Hal itu dilakukan dengan review materi sebelum melanjutkan, menyesuaikan materi dengan media / sumber belajar; dan (3) evaluasi pembelajaran yang diberikan guru sesuai dengan tujuan pembelajaran yang telah ditetapkan, yaitu mencakup nilai karakter siswa, penilaian kemampuan memahami konsep, nilai keterampilan siswa dan nilai sikap dalam proses pembelajaran. Evaluasi dilakukan setiap selesai satu materi pokok bahasan pelajaran.

\section{Kesimpulan} berikut:

Berdasarkan hasil Penelitian Tinadakan Sekolah (PTS) dapat disimpulkan sebagai

1. Pembinaan yang dilakukan kepada guru produktif pada program keahlian desain dan produksi kria jika dilaksanakan secara konsisten dapat meningkatkan kinerja guru SMK Negeri 2 Sukawati dalam melaksanakan Pembelajaran membatik pada program keahlian desain dan produksi kria tekstil

2. Guru menunjukkan keseriusan dalam memahami dan menerapkannya dalam pembelajaran mata pelajaran membatik setelah memperoleh pembinaan kompetensi profesional dari kepala sekolah dan merasa sangat bermakna dalam upaya meningkatkan kinerja mereka

3. Berdasarkan hasil wawancara dan observasi yang dilakukan oleh Peneliti bahwa dengan dilaksanakannya pembinaan kompetrensi profesional bagi guru produktif para guru terfasilitasi untuk melakukan hal terbaik dalam melaksanakan pembelajaran serta mendapat bimbingan yang sangat berharga untuk membuka wawasan guru SMK Negeri 2 Sukawati khususnya guru mata pelajaran produktif membatik, sehingga dapat meningkatkan kinerja guru dalam melaksanakan Pembelajaran membatik

4. Peningkatan terjadi sangat signifikan

Penelitian Tindakan Sekolah (PTS) yang dilaksanakan di SMK Negeri 2 Sukawati telah terbukti mampu meningkatkan kinerja guru produktif dalam melaksanakan pembelajaran. Dengan dilaksanakannya progarm pembinaan kompetensi profesional bagi guru produktif pada program keahlian desain dan produksi kria secara konsisten dapat meningkatkan motivasi dan kompetensi guru dalam melaksanakan pembelajaran dengan benar. Oleh karena itu, peneliti menyampaikan beberapa saran sebagai berikut:

1. Semangat dan motivasi guru yang sudah tertanam dalam melaksanakan pembelajaran hendaknya terus dipertahankan dan ditingkatkan / dikembangkan, untuk meningkatkan mutu pembelajaran di SMK Negeri 2 Sukawati .

2. Program pembinaan kompetensi profesional baik dilanjutkan bagi guru lainnya karena memberi dampak yang positif untuk meningkatkan mutu pembelajaran di SMK Negei 2 Sukawati

3. Program pembelajaran yang telah disusun hendaknya di kemas menjadi satu naskah dokumen pembelajaran dan dibuat rangkap untuk di administrasikan agar lebih mudah dalam pengelolaan administrasi sekolah serta mencarikan bila diperlukan

4. Dengan memperhatikan kelemahan-kelemahan pada pelaksanaan Penelitian ini diharapkan bagi guru yang ingin melakukan Penelitian Tindakan Kelas ( PTK) demikian juga bagi Kepala Sekolah yang ingin melakukan Penelitian Tindakan Sekolah (PTS), lebih lanjut agar dapat meminimalisasi kelemahan-kelemahan tersebut supaya hasil yang diperoleh menjadi lebih baik.

5. Kepada para pembaca yang ingin melakukan Penelitian Tindakan Kelas (PTK) atau Penelitian Tindakan Sekolah ( PTS), disarankan agar dalam melakukan tindakan dan refleksi dapat dilaksanakan secara mendalam dan fokus terhadap kelemahan-kelemahan yang terjadi, untuk memperoleh hasil yang baik sesuai dengan tujuan yang ingin dicapai. 


\section{Daftar Pustaka}

Arikunto, S dan Suhardjono. 2009. Penelitian Tindakan Kelas. Jakarta: Bumi aksara.

Asiah. T, Siti. 2016. Efektivitas Kinerja Guru. Jurnal Manajemen Pendidikan Islam Volume 4 Nomor 2. http://journal.iaingorontalo.ac.id/index.php/. Diakses 17 Mei 2019.

Bermawi, M. 2005. Strategi Pembelajaran Aktif. Jogyakarta.CTSD.

Depdiknas. 2001. Buku 1 Manajemen Peningkatan Mutu Pendidikan Berbasis Sekolah. Jakarta: Depdiknas.

Fitriani, dkk. 2015. Kompetensi Profesional Guru Dalam Pengelolaan Pembelajaran di Mts Muhammadiyah Banda Aceh. Jurnal Magister Administrasi Pendidikan Pascasarjana Universitas Syiah Kuala ISSN 2302-0156.

Khodijah, Nyayu. 2013. Kinerja Guru Madrasah dan Guru Pendidikan Agama Islam Pasca Sertifikasi di Sumatera Selatan. Cakrawala Pendidikan No. 1. http://lppmp.uny.ac.id/sites/lppmp.uny.ac.id/. Diakses 17 Mei 2019.

Nana Sudjana. 2002. Penilaian Hasil Proses Belajar Mengajar. Bandung: Remaja Rosdakarya.

Niken Widagdorini, Hendrawati. 2017. Kinerja Guru dalam Meningkatkan Mutu Pendidikan Melalui Kurikulum 2013 di SD Negeri Timpik 01 Tahun 2017. http://eprints.ums.ac.id/. Diakses 17 Mei 2019.

Ning Zahroh, Mas. 2016. Evaluasi Kinerja Guru dalam Peningkatan Mutu Pendidikan di Yayasan Al Kenaniyah Jakarta Timur. Jurnal Manajemen Pendidikan. https://www.neliti.com/id/publications/. Diakses 17 Mei 2019.

Ode Ismail Ahmad, LA. 2017. Konsep Penilaian Kinerja Guru Dan Faktor Yang Mempengaruhinya. Jurnal Idaarah Vol. I No. 1. http://journal.uinalauddin.ac.id/index.php/. Diakses 17 Mei 2019.

Purwanto. 2011. Evaluasi Hasil Belajar. Yogyakarta: pustaka pelajar.

Rahadi, Ansto. 2003. Media Pembelajaran Jakarta : Dikjen Dikti Depdikbud.

Slameto, Bambang S, dkk. 2017. Peningkatan Kinerja Guru melalui Pelatihan beserta Faktor Penentunya. Jurnal Pendidikan IImu Sosial Vol. 27 No. 2 Hal. 38-47. http://journals.ums.ac.id/index.php/. Diakses 17 Mei 2019.

Srinalia. 2015. Faktor-Faktor Penyebab Rendahnya Kinerja Guru dan Korelasinya terhadap Pembinaan Siswa: Studi kasus di SMAN 1 Darul Imarah Aceh Besar. Jurnal IImiah Didaktika Vol. 15 No. 2. https://media.neliti.com/media/publications/. Diakses $17 \mathrm{Mei}$ 2019.

Sudjana. 2001. Media Pengajaran. Jakarta : Sinar Baru Algensindo.

Zubair, Ahmad, dkk. 2017. Manajemen Peningkatan Kinerja Guru. Manajer Pendidikan, Volume 11 Nomor Hal. 304-311. https://media.neliti.com/media/publications/. Diakses $17 \mathrm{Mei}$ 2019. 